DEUÍFD Türk Kültürünü Mayalayanlar Özel Sayısı / 2021, ss. 799-815.

\title{
DEDE KORKUT'UN KIRK İNCE BELLİ KIZLARINDAN BÂCIYÂN-I RÛM TEŞKİLATINDA SOSYAL ÖRGÜTLENMENİN İZLERİ*
}

Ümral DEVECI**

\section{ÖZ}

Ahîlik oluşumu içinde ortaya çıkan ve varlığı konusunda ise araştırmacıların tartısmalarına vesile olan tarihteki ilk kadın birliği olarak da kabul gören "Bâcıyân-1 Rûm" teşkilatı, 13.yy da Türkmen kadınlarının birçok konuda birlikte hareket ettikleri, usta- çırak ilişkisi içerisinde kadınların pek çok açıdan eğitildiği bir örgütlenme prototipidir.

Dönemin şartları gereği hem üretim hem savaş/mücadele, hem de savunma/yurdunu koruma konusunda da katkı değer oluşturan kadınların birlikte belirli bir düzen ve hiyerarşi içinde oluşturdukları bu sosyal oluşumunun izlerini, varlı̆̆1 8. yüzyıla dek dayandırılan Dede Korkut anlatılarında sürmek mümkündür. Her ne kadar yazıya geçirildikleri dönem itibariyle İslamiyet'in etkisi hissedilse de Dresden ve Vatikan nüshalanındaki günümüze ulaşmış 12 anlatıdaki kadın profillerine baktığımızda Bâcıyân-1 Rûm teşkilatındaki kadınların konumları ve özellikleriyle örtüşen bir paralellikten söz edilebilir. Özellikle Dede Korkut'taki beylerin eşlerinin 40 ince belli kız eşliğinde ava, savaşa gittikleri, yurtlarını korudukları, iş birliği içinde ilaç yaptıkları, hanımlarını korumak için bir plan dâhilinde hareket ettikleri anlatılmaktadır. Boyu Uzun Burla Hatunun, Dirse Han'ın Hatununun maiyetlerindeki 40 ince belli kızla birlikte hareket ederek anlatıların kurgusuna yön verdikleri görülmektedir. Bunların yanı sıra savaşçı/alp kadın özellikleri taşıyan Banu Çiçek’i ve Selcen Hatun'u da bunların dışında tutmak mümkün değildir.

Sonuç olarak denilebilir ki; her ne kadar yeterli belge bulgu olmadığı için tartışmalara açık olsa da Bâcıyân-1 Rûm teşkilatını, -karakteri gereği Dede

* Yazar; çalışmanın hazırlanması esnasında bilimsel ve etik ilkelere uyulduğunu ve yararlanılan tüm kaynakların kaynakçada belirtildiğini, çalışmanın maddi açıdan fonlanmadığını, çıkar çatışması bulunmadığını beyan etmektedir.

** Doç. Dr. Muğla Sıtkı Koçman Üniversitesi, Edebiyat Fakültesi Türk Dili ve Edebiyatı Bölümü, udeveci@mu.edu.tr, ORCID ID: https://orcid.org / 00000002-1834-64357

Makalenin Hakemlere Gönderiliş Tarihi : 06/12/2021

Makalenin Hakemlerden Geliș Tarihi $\quad$ : 17/12/2021 
Korkut Anlatılarında karşımıza çıkan hatun ve maiyetlerindeki kızlar bağlamında değerlendirdiğimizde- sosyal tarih çerçevesinde var olan bir geleneğin devamı olarak işaretleyebiliriz.

Anahtar Kelimeler: Bâcyyân-1 Rûm Teşkilatı, Ahî Evran, Dede Korkut Anlatıları, sosyal örgütlenme.

\title{
FROM DEDE KORKUT'S FORTY SLIM WAIST DAUGHTERS TO THE TRACES OF SOCIAL ORGANIZATION FOR THE BACIYAN-I RUM ORGANIZATION.
}

\begin{abstract}
The "Bâciyân-1 Rûm" organization, which emerged within the Ahî-order formation and is accepted as the first women's union in history despite the discussions of the researchers about its existence, is a prototype of organization in which Turkmen women acted together in many issues in the 13th century and were educated in many aspects within the master-apprentice relationship.

It is a social formation formed in a certain order and hierarchy by women, who contribute value both in production, war/struggle, and defense/preservation of their homeland, due to the conditions of the period. It is possible to find the traces of this organization in Dede Korkut's narratives, whose existence dates back to the 8th century. Although the influence of Islam was felt in the period they were written, when the women profiles in the 12 extant narratives in the Dresden and Vatican copies are analyzed, it is possible to talk about a parallelism that coincides with the positions and characteristics of the women in the Baciyan-Greek Organization. It is told that the wives of the lords in Dede Korkut, accompanied by 40 thin waisted girls who acted within a plan to protect their lady, went to the hunt and war, protected their homeland and made medicine in cooperation. Lady Burla seems to direct the fiction of the narratives by acting together with the $40 \mathrm{slim}$-waisted girls in the entourage of Dirse Han's Lady. In addition to these, it is not possible to exclude Banu Çiçek and Selcen Hatun, who have warrior/alpine woman characteristics.

As a result, it can be said that although it is controversional due to the lack of sufficient documentation, we can mark the Bâciyân-1 Rûm Organization as a continuation of a tradition that exists within the framework of social history, when evaluated in the context of the women and girls in their entourage, who appear in the Dede Korkut Narratives.
\end{abstract}

Keywords: Bâciyân-1 Rûm Organization, Ahî Evran, Dede Korkut Narratives, social organization. 


\section{GİRİŞ}

İnsanoğlu birlikte hareket etmenin güç kazandırdığını fark ettiği andan itibaren sosyalleşmenin ve örgütlülügün temellerini de atmıştır. Özellikle tabiat gibi bir gücün karşısındaki zayıflı̆̆1 onu kendi türdeşleriyle yakınlaşmaya ve birlikte hareket etmeye sevk etmiş olmalı ki, zaman da bu birlikteliklerin düzenli topluluklara evrilmesine imkân tanımış, bu birliktelikler her devirde lider ihtiyacını da doğurmuştur. Mitik dönemlerde tanrıları tasavvur edip onun varllğı karşısında yakınlaşan ve dini topluluklar oluşturan, tabiat karşısındaki çaresizliklerini anlamlandırmaya çalışan insanlar; destan döneminde kahraman olarak addettikleri şahsiyetler etrafında toplanarak güç birlikteliği yapıp milletleri oluşturma yoluna gitmişlerdir. Daha sonraki süreçlerde ulusların varlığ1 siyasi liderleri doğurmuştur. Birçok koldan çağa göre şekillenen dini otoriteler, kendi topluluklarının liderlerini yaratmaya devam ederken buna paralel olarak da yine birçok koldan dünyaya hükmeden siyasi oluşumlar ve onları yönlendiren liderler ortaya çıkmıştır. Kısacası insan, sosyal bir varlık olarak kendini anlamaya başladığ1 andan itibaren topluluklar içinde kendi kimliğinin peşine düşmüş ve bir topluluğa ait olarak örgütlenmenin kendine fayda sağladığını ayrıca hayatta kalmasına yardım ettiğini fark etmiştir.

Ataerkil dünya düzeni içinde bu örgütlenmelerin daha çok eril alt tabanlı olduğu ve daha çok da bunların tespit edilip yazılıp çizildiği bilinmektedir. Mutlaka bu durumun da sosyolojik temelleri vardır ve belki de hala araştırılmaya muhtaçtır. İnsan denilen tür, aynı zihinsel işleyişe sahip iki farklı cinsiyetin varllğ̆ ile mevcuttur. Dolayısıyla tarihsel süreçte ortaya çıkan her türlü olgudan, oluşumdan eş zamanlı ve aynı derecede etkilenmiş oldukları muhakkaktır. Kadınlar da tarihsel süreç içinde onları hayatta tutacak kendilerine çocuklarına, ailelerine ve hatta dâhil oldukları topluluğa fayda sağlayacak örgütlü ya da örgütsüz çeşitli topluluklar kurmuşlar ya da bu topluluklara dâhil olmuşlardır.

$\mathrm{Bu}$ makalenin konusu, Anadolu'da Ahîlik teşkilatının bir alt oluşumu olarak sınıflandırılan, kadınların sosyal örgütlenmesinin ilk örneklerinden sayılan, 13.yy' da varlığından söz edilen Bâcıyân-1 Rûm teşkilatı ve onun geçmişe dayanan izlerinin varlığıdır. Bu izleri örneklendirmek adına Dede Korkut Hikâyelerine başvurulacaktır. Dolayısıyla bu makalede, Bâcıyân-1 Rûm teşkilatındaki örgütlenmenin, anlatılarda bey hatunları ve onların maiyetindeki "kırk ince belli kı" diye 
ifade edilen toplulukla benzerliğine vurgu yapmanın doğru olacağ1 kanaatindeyiz.

\section{BÂCIYÂN-I RÛM TEŞKİLATI}

Bâcıyân-1 Rûm teşkilatının tarihsel geçmişi ile ilgili çok net bilgi bulunmamaktadır; Âşık Paşazâde (1481), "Tarih-i Âl-i Ossman" adlı eserinde bilindiği üzere Anadolu Selçukluları devrinde Türkmenler arasındaki sosyal zümreleri dört grupta sınıflandırmıştır: Gâziyân-1 Rum (Anadolu Gazileri), Âhiyân-1 Rûm (Anadolu Ahîleri), Abdalân-1 Rûm (Anadolu Abdalları), Bâcıyân-1 Rûm (Anadolu Bacıları). Âşı1k Paşazâde'nin Haciyân-1 Rûm diye de nitelendirmiş olduğu Bâciyân-1 Rûm teşkilatı Alman müsteşrik Franz Taeschner'in de dikkatini çekmiştir. Taeschner, kadınlardan oluşan böylesi bir teşkilatın varlığına inanmak istememiştir. Bunun Âşık Paşazade tarafindan yanlışlıkla yazılmış olabileceğini, hatta aktarım hatası olabileceğini düşünmüştür, daha sonraları Fuad Köprülü yapmış olduğu araştırmaları ve Bektâşi rivayetlerini dikkate aldığında böyle bir topluluğun varlığını kabul etmiş ancak bu topluluğun amacinın ne olduğunu $\mathrm{O}$ da açılığ kavuşturamamıştır. Hatta bunun kadınlardan oluşmuş bir tarikat olduğu ihtimali üzerinde durmuştur; "Acaba Paşazade, Bâcıyân-1 Rûm ismi altında uç beyliklerindeki Türkmen kabilelerinin müsellah ve cengâver kadınlarından $\mathrm{m}$ bahsediyor? Şimdilik akla en yakın gelen te'vil bu görünüyor" şeklinde fikir yürütmüştür ${ }^{1}$."

Osmanlı kroniklerinde de Osmanlı devletinin zuhuru sırasında Türkmen kadınlarının uç bölgelerde faaliyet gösterdiklerinden söz edilmektedir. Fuad Köprülü’nün aktarımıyla Mağribli bir seyyah olan İbn Battuta XIV. asrin ortalarında yani Orhan Gazi zamanında Anadolu'nun birçok yöresinde Türkmenler arasında bulunmuş ve Türkmen hanımlarının çeşitli faaliyetlerine şahit olduğunu aktarmıştır. Niğdeli Kadı Ahmed 1340 yllında tamamlamış olduğu “el- Veled' üş- Şefik adlı eserinde ise Niğde dolaylarında Tapduklu Türkmen dervişlerinin

\footnotetext{
Mikail Bayram (1999) "Bacıyan-Rum (Anadolu Bacıları) ve Fatma Bacı", Türkler Ortaçăg, C.6, Ankara: Yeni Türkiye Yayınları, s. 368; Kasım Tatlllığlu (2012). "Ahîlik Teşkilatında Anadolu Türk Kadınının Girişimciliğine Sosyal-Psikolojik Bir Yaklaşım”, Bingöl Üniversitesi Sosyal Bilimler Enstitüsü Dergisi Y11: 2/ Cilt: 2 /Say1: 4/ Güz, s.83.
} 
hanımlarının faaliyetlerinden söz etmiştir. XIV. asırda Moğolların Anadolu'yu işgali ile birlikte Anadolu Selçuklu Devleti Moğol egemenliği altına girince içlerinde Bacı teşkilatının da bulunduğu pek çok teşkilatı dağıtmışlardır (Bayram 1999:365,366). Âşık Paşazade eserinde Hac1 Bektâş-1 Velînnin bacılara olan yakınlığını ve bu teşkilatın ileri gelenlerinden olan Hatun Ana'ya olan bağlılığını ve gizli ilim ve kerametlerini Hatun Ana'ya gösterdiğini, neyi varsa onları Hatun Ana'ya emanet ettiğini yazmaktadır. Hatun Ana'nın Hacı Bektaş'ın ölümünden sonra onun mezarını yaptırdığını da belirtmektedir. Hacı Bektâş-1 Velî’nin Menakıbnamesi olan Velayetnamesinde bu hatunun adı Fatma Ana, Fatma Bacı, Kadıncık Ana, Kadıncık biçimlerinde geçmektedir. Menâkıb1 Şeyh Evhadü'd-Dîn-i Kirmânî'deki bilgilere göre; Şeyh Evhadü'd-Dîni'nin kızı Fatma Anadolu'da debbağların piri olarak bilinen Ahî Evren Hace Nasreddin Mahmud'un eşi olduğu bilgisine ulaşılmaktadır. Ahî Evrân Hâce, Nasreddin Mahmud'un 1205 yllında hocas1 Evhadü'd-Dîn-i Kirmânî ile birlikte Anadolu'ya geldiği bilinmektedir. Bazı kayıtlarda da debbağların piri ve Anadolu Ahîliğinin baş mimari olarak bilinen Şeyh Nasreddin Mahmud b. Ahmed el-Kirmani'” nin 1206 yllinda Kayseri'ye yerleşerek orada bir debbağ atölyesi kurduğu belirtilmektedir ${ }^{3}$.

Moğolların Kayseri'yi işgali sırasında Ahîlerin ve Ahî kadınlarının kılıçtan geçirildiği, Fatma Bacı'nın da bir grup genç kızla birlikte Moğollara esir düştüğü rivayet edilmektedir. Babasının itibarından dolayı Moğolların Fatma Bacı'ya kötü davranmadıkları, ancak 15 yıla yakın esir tuttukları aktarılmaktadır. Esaretten kurtarılan Fatma Bacı'nın kocası bir iki yıl sonra öldürülür. Fatma Bac1, bir süre sonra ikinci ve hatta üçüncü evliliğini gerçekleştirir. Hacı Bektâş-1 Velî’nin türbesini yaptırmış olduğu ileri sürülen Fatma Bacı'nın Hacı Bektâş-1 Velî’nin ölüm tarihinde (1271) yaşamakta olduğu düşünülmektedir. Öte yandan Hac1 Bektâş-1 Velî’nin Orhan Gazi ile de çağdaş kabul edildiğinden dolayı da Orhan Gazi zamanına kadar yaşamış olabileceği mümkün görülmemektedir. Dolayısıyla ölüm tarihi hakkında kesin bir bilgiye ulaşılmamıştır ${ }^{4}$.

2 Söz konusu şahsın Nasreddin Hoca olduğu ve fikralarda geçen karısı Fatma'nın da Fatma Bacı olduğu ileri sürülmektedir. Bayram 1999: 368-369.

3 Bayram 1999: 368.

$4 \quad$ Bayram 1999: 372-373. 
Menâkıb-1 Şeyh Evhadü'd-Dîn-i Kirmânî’nin yazarı ve Şeyh Evhadü'd-Dîn-i Kirmânî'nin Sivas'taki halifesi olan Şeyh Şemseddin Ömer et- Tiflisi, eserinde Bâciyân-1 Rûm 'un liderlerinden olan Şeyh Evhadü'd-Dîn'in iki kızlarından söz ederken Şam'a yerleşen ve siyasi olaylardan uzak duran Emine Hatun'u över ve ondan sayg1 ile söz ederken Anadolu'daki siyasi olaylara katıldığı için Fatma Bacı'yı (Fatma Hatun) kötülemekten kendini alamamıştır. Velayet-name'de adı geçen Fatma Bacı'nın (Kadıncık Ana) Menâkıb-1 Şeyh Evhadü'd-Dîn-i Kirmânî'de geçen Şeyh Evhaddedin Hamid el-Kirman'inin kızı Fatma Hatun ile aynı kişi olduğu ve her ne kadar Velayet-name'de Fatma Bacı'nın Sivrihisarlı Nureddin'in kızı, manevi evladı ya da sadece yakıştırma olarak gösterilse de Âşı Paşazade de Hacı Bektaş Veli’nin Fatma Ana'y1 kendine evlat edindiğini belirtmektedir ${ }^{5}$. Bu konuda araştırmalar yapan Mikail Bayram Bâcıyân-1 Rûm ile ilgili en ilginç bilgileri Menâkıb-1 Şeyh Evhadü'd-Dîn-i Kirmânî’nin eserinde bulduğunu ifade etmektedir. Anadolu Selçukluları zamanında bu hanımların teşkilatının adının Fakîregân olduğunu belirtmekte, ancak teşkilattaki kadınların birbirlerine Bacı olarak seslendikleri için bu teşkilatın Bâcıyân-1 Rûm olarak adlandırıldığını hatta bu ifadeyi ilk kullananın da Âşı Paşazade olduğunu aktarmaktadır ${ }^{6}$.

\section{1.Bac1ların Faaliyetleri}

Ahîlik anlayışı çerçevesinde, Bacılar da meşgul oldukları sanatları, gelenek halinde sürdürmüşlerdir. Ahîlik ve Bacılık oluşumlarında da tıpkı tasavvuf eğitiminde olduğu gibi ustadan el ve izin almak gerekmektedir. Üstattan el almadan onun rehberliğinde yol almadan bir sanatı icra etmeye başlamak caiz değildir ve kabul görmez. Bacılık sadece eğitim ve öğretim ocağı değildir, aynı zamanda bu ocakta mal üretmek ve topluma hizmet sunmak da bir o kadar önemlidir. Ayrica bunun yol, yordam ve kaidesi içinde yapıldığı, Ahîlikteki usta, kalfa, çırak ilişkisi bağlamındaki hiyerarşinin bacılar arasında da olduğu ön görülmektedir. Aynı zamanda bu teşkilatların içinde yer alanlara dini ve ahlaki bilgiler de kazandırılır ve bu konulara Ahîlik de olduğu gibi Bacılık teşkilatında da titizlik gösterilmiştir.

\footnotetext{
5 Bayram, 1999: 366-369.

6 Bayram, 1999: 366.
} 
Fatma Bacı, Bacı teşkilatının ilk kurulduğu yer olan Kayseri Külah-duzlar Mahallesinde bacilarla birlikte örgü ve dokumacillk yapmıştır. Moğolların işgalinden ve buranın yakılıp yıkılmasından sonra esaretten kurtulan Fatma Bacı'nın, yerleştiği Kırşehir'de bu işleri maiyetindeki kadınlarla beraber devam ettirdiği ifade edilmektedir. Bektaşî dervişlerinden Abdal Musa'nın başına taktı̆̆1 ak börkün (bükme elif taç), bacılar tarafından imal edilen külahlardan olduğu rivayet edilmektedir ki bu börklerin yeniçerilerin giydikleri akbörk ile benzer olduğu tespit edilmiştir. Âşık Paşazade bu külahların menşeini, bacıların Kayseri ve Kırşehir'de imal ettikleri külahlarla olan benzerliklerinden dolayı bacıların sanatıyla ilişkilendirmektedir. Sadece külahların değil çeşitli giysilerin hatta yeniçeri giyimlerinin de bacıların atölyelerinde imal edildiği düşünülmektedir. Bunların yanı sıra Osmanlıların kuruluş dönemindeki askerlerin kıyafetlerinin de bacıların tezgâhlarından çıktığı kabul edilmektedir. Bacıların Kayseri'deki atölyelerinde kumaş, kilim ve halı dokudukları, Külah-duzlar çarşısında dokuma ve örgü tezgâhlarının bulunduğu ifade edilmektedir. Çadırcılık, keçecilik, nakışçlık, örgücülük, ipek ve pamuk ipliği üretimi gibi pek çok alanda hizmet verdikleri bilinmektedir. Ahîlerle birlikte bacıların da Orta Anadolu'dan uç bölgelere gidince sanatlarını da birlikte götürdükleri ve bu uç bölgelerde kurulan Germiyanoğullarında bu işlerini devam ettirip halı, kumaş, tülbent gibi malzemeler üretip sattıkları aktarılmaktadır. Örnekleri günümüze ulaşmış olan Anadolu Selçuklular devrine ait halı, kilim ve kumaşların bacıların atölyelerinde geliştirilip üretildikleri araştırmacılar tarafından kabul görmektedir. Bacı teşkilatı, başlangıçta Ahîlikle birlikte Kayseri, Kırşehir, Konya, Ankara, Larende gibi merkezlerde kurulmuş ancak daha sonraları Moğol zulmünden kaçarak uç bölgelere yerleşmişlerdir. Ahîlik ve Bacıllı teşkilatı ile birlikte halı, kilim, kumaş dokumacılı̆̆ı da Anadolu'da köylere kadar ulaşmış ve yerleşmiştir?.

\subsubsection{Askeri Faaliyetlere Katkı Sağlama}

Bacıların, savaş meydanlarında da etkin olduklarına dair, bazı kaynaklarda yer verilmiştir. İslam öncesi çağlardan itibaren Türk kadınlarının binicilikte ve silah kullanımında maharetli oldukları bilinmekte ve tarihi kayitlarda bunlardan söz edilmektedir. İslamiyet’le

$7 \quad$ Bayram, 1999: 374-375; Tatlllığlu 2012: 82. 
birlikte bu gelenek devam etmiş, (Bayram'ın, Ravendî'den aktarımıla) Harzemliler ve Iraklılar arasındaki 1197 tarihindeki savaşta, Harezmli kadınların zırh giyip savaşa katıldıkları ve her kadının yaklaşık 50 Irak askerini savaş meydanından sürüp çıkardığ1 rivayet edilmiştir. İbn Battuta'da birçok Türk ilinde özellikle de Özbekler arasında "Havâtin (Hatunlar)" diye adlandırılan Türk kadınlarının savaşçı özelliklerine rasgeldiğini ifade etmektedir ${ }^{8}$. Moğolların Kayseri'yi kuşatmaları esnasında (1243), Bacıların şehrin savunmasına katıldıkları, teşkilat olarak savaştıkları bilinmektedir. Uç bölgelerde de Türkmen aşiretleri arasında Bacı örgütüne mensup savaşçı kadınların bulunduğu hakkında bilgiler mevcuttur?.

\subsubsection{Konuk Ağırlama}

Bacıların faaliyetlerinden biri de tekke ve zaviyelerde ağırlanan konukların yeme, içme, temiz çamaşır gibi ihtiyaçlarını karşılamaktı. Ahî tekkelerinin kuruluşuna zemin hazırlayan şeylerden biri de büyük topluluklar halinde insanların yerlerinden yurtların kopmak zorunda kalıp Anadolu'ya göç etmeleriydi. Bu göçler aynı zamanda Anadolu'yu İslamlaştırmaktaydı. Anadolu'ya gelenlerin ortama uyum sağlayabilmelerini ve ağırlanmalarını Ahîlik teşkilatları üstlenmişti ve dolayısıyla bacılar da konuk ağırlama aşamasında devreye girmişlerdi.

Hacı Bektâş Menakıbnamesinden aktarıldığ1 üzere, Hacı Bektâş Velî Anadolu'ya geldiği zaman, henüz genç kız olan Fatma Bacının erenlere yemek pişirip sofra düzenlerken durumu fark edip onun geldiğini erenler meclisine haber verdiği belirtilmektedir. Bundan yola çıkılarak Hacı Bektâş Velî’nin Anadolu'ya geldiği 1228 yılında, Bac1 teşkilatının kurulmuş olduğu, bir süre Hac1 Bektâş-1 Veli'nin, Ahî misafirhanelerinde konuk edildiği anlaşılmaktadır. 13. yüzyılda Anadolu'da kadın faaliyetlerinin iki-üç asır sonrası ile karşılaştırıldığında oldukça yoğun olduğu ve bu durumun özellikle Anadolu'ya göç etmiş Türkmen kadınlarının Hacı Bektâş Velî’den aldıkları ilhamla, Anadolu'nun Türkleşmesi ve İslamlaşması yönünde büyük hizmetler

\footnotetext{
Bayram,1999: 375.

9 Bayram,1999: 375.
} 
gerçekleştirdikleri, zaviyeler kurdukları, buralarda görev aldıkları o döneme ait vakıf kayıtlarından bilinmektedir ${ }^{10}$.

Ayrıca Velayetnamede Fatma Bacı'nin kimsesizleri, yoksulları barındırdığı, misafir ağırladığı ve maiyetindeki kızlarla pek çok imece usulü ile işler yaptığı da anlatılmaktadır. Menâkıb-1 Şeyh Evhadü'd-Dîn-i Kirmânî'deki bilgilere göre; Fatma Bacı'nın babası Șeyh Evhadü'd-Dîn'in kızına ve etrafindaki kadınlara yolcuların ve kimsesizlerin bakılıp kollanması, yedirilip içirilmesi ve kişisel ve giysilerinin temizliklerinde yardımcı olunması gerektiğini telkin ettiği ve bunun ne kadar sevap bir davranış olduğunu anlattığı belirtilmektedir. Şeyh Evhadü'd-Dîn, ahîliği tanımlarken malını mülkünü cömertçe yoksula ve yolcuya harcamanın amaç edinildiği bir teşkilat olması gerekliliğini belirtmiştir. Kirmâni, her iki kızının da eğitimine büyük önem vermiş, onların düzenli eğitim almalarını ve el sanatlarını da öğrenmelerini sağlamıştır. Kadınların eğitim görmesine verdiği bu önem yüzünden zaman zaman da eleştirilmiştir. İbn Battûta da seyahat yazılarında Anadolu'nun birçok yöresindeki Ahî misafirhanelerinde şahit olduğu Türkmen kadınlarının misafir ağırlama yeteneklerinden ve çabalarından övgü ile söz etmiştir ${ }^{11}$.

Bacılar ayı zamanda dini ve kültürel faaliyetlerini de bir tarikat disiplini ve metodu içinde gerçekleştirmiş olduklarından, Fuad Köprülü ve kimi araştırmacılar Bâcıyân-1 Rûm teşkilatının kadınlardan oluşmuş tarikat olduğunu düşünmüşlerdir. Ancak araştırmalar göstermiştir ki, bu teşkilat Ahîlik teşkilatının kadın koludur. Kadınlardan oluşmuş bu cemaatin lideri de Fatma Bacı'dır. Bacı teşkilatının üyeleri kadınlar, erkeklerle bir arada zikir, sema ve sohbet meclislerinde bulunmuşlardır ve dönemindeki kimi şeyhler tarafindan eleştirilse de tasavvuf tarihinde, bu kadın ve erkek birlikte ibadet etme halinin tarihçesi Anadolu Selçukluları zamanından çok daha öncesine dayanmaktadır. Selçuklular zamanında Türkmen hanımlarının da kadınlı erkekli sohbet meclislerine ve kültürel faaliyetlere katıldıkları bilinmektedir. Şeyh Evhadü'd-Dîn döneminde kadınlı erkekli semaya katılanların eline kandil verildiği, karanlıkta sema

10 Hatice Çubukçu (2015). "Bâcıyân-1 Rûm ve Anadolu Tasavvufundaki Yeri”" FSM İlmî Araştırmalar İnsan ve Toplum Bilimleri Dergisi, 5 Bahar, s.230.

11 Bayram, 1999: 375-376. 
dönen gençlerle kandilin uyumunun, sonraları çayda çıra oyununun oluşumuna zemin hazırladığı belirtilmektedir ${ }^{12}$.

Bu bilgiler bize 13.yy'da bir kadın örgütlenmesi olan Bâcıyân-1 Rûm teşkilatının, kendi içerisinde özgün bir hiyerarşiye sahip olduğuna, misafir ağırlamak, yemek yapmaktan giysi ve ev eşyası üretmeye, dini törenler düzenlemeye ve katılmaya, imece geleneğini devam ettirmeye varan pek çok kolda faaliyet gösterdiklerine, günlük yaşam düzenine katkılarının yanı sıra savunma ve savaşçı yanlarıyla da içinde bulundukları topluma katkı sağladıklarına işaret etmektedir. Ancak bu kadın örgütlenmesinin 13. yy'da birdenbire ortaya çıkmış olması mümkün değildir. Kayıtlara geçmemiş ya da ulaşllan kayıtlarda bilgilere rastlanmamış olsa da eski bir geleneğin izlerini taşıdığı muhakkaktır.

Bu bağlamda baktığımızda bize bir fikir vermesi açısından 15 . yüzyılda yazıya geçirilmiş olduğu düşünülen Dede Korkut Kitabı'ndaki hikâyelerde benzer faaliyetler gösteren hatunların ve maiyetlerindeki kırk $^{13}$ ince belli kızın, Oğuzlar arasındaki prototip bir kadın örgütlenmesinin varllğını ortaya koyduğunu söylemek mümkündür.

Konuyla ilgili alan yazın tarandığında ${ }^{14}$; Dede Korkut Kitabı'ndan verilen örneklerde, "mukaddime" bölümündeki kadınların sinıflandırılması, makbul kadının örneklenmesi ve kadınların misafirperver davranışlarına ya da bey hatunlarının ya da kızlarının savaşç1 -alp kadın- kimliklerini işaret eden örneklerle sınırlı kalındığı görülmüştür. Mukaddime bölümünde, Dede Korkut anlatılarını yazıya geçiren müellif, Dede Korkut'un şahsiyeti ve anlatıların içeriği hakkında bilgi verirken aynı zamanda kendi yaşadığı asır içindeki toplumun kadınlar hakkındaki düşüncelerini de yansıtmıştır. Bu çerçeve de değerlendirildiğinde Bâcıyân-1 Rûm Teşkilatı için en iyi örneklendirme,

12 Bayram, 1999: 377.

13 Kırk kız ile ilgili anlatmalara pek çok efsane ve destanda da rastlamak mümkündür. Örneğin Kırg1z Türk topluluğunun menşeini anlatan "Kırk Kız” efsanesi bunlardan biridir. Bkz. Meral Demiryürek (2017). "Kurk Kız Efsanesinin Yazılı Kültürdeki İki Örneği Üzerine Bir Değerlendirme”, Millî Folklor, Yıl: 29, Sayı:116, s. 47-57.

14 Tatlılıŏlu 2012: 87; Selahattin Dögüş (2015). “Kadın Alplardan Bacıyan-Rum'a (Anadolu Bacılar Teşkilatı)"; Türklerde Kadının Siyasi ve Sosyal Mevkii, Cilt:12, Say1 1, s 140-141. 
bey hatunlarının liderliğindeki kırk ince belli kızlar topluluğu ve onların sosyal hayat içerisindeki işlevleri, görevleri, duruşları olmalıdır.

\section{DEDE KORKUT ANLATILARI}

Dede Korkut anlatılarında beylerin yanında yer alan ve savaşta ve barışta birlikte hareket eden ve hiyerarşik düzene tabi olan 40 yiğidin yanı sira, hatunların maiyetinde de 40 ince belli k1zın ${ }^{15}$ anlatılarda siklikla vurgulandığ1 görülmektedir. $\mathrm{Bu}$ kadınlar, anlatılarda aktarıldıkları biçiminde -gerektiğinde- savaşç1 olmalarının yanı sıra ${ }^{16}$, hatunun liderliğinde hareket eden birçok gündelik işi birlikte yapan ve sürekli bir dayanışma içinde olan kadınlar topluluğu olarak ifade edilebilir. "Kırk ince belli kız" ifadesinden yola çıkıldığında, hatunların maiyetinde olan bu kadınların, seçilmiş ve pek çok konuda eğitim almış olabileceklerini varsaymak yanlış olmaz. Yine anlatılardan yola çıkıldığında; doğanın dilini iyi bildiklerini, otları ve bitkileri iyi tanıdıklarını, gerektiğinde otlardan ilaç yaptıklarını; sır sakladıklarını, güvenilir ve korumacı olduklarını, gündelik işlerde birlikte hareket ettiklerini; dara düşüldüğünde silahlarını kuşanıp kayıplarını aradıklarını, esir düşen yakınlarını kurtardıklarını ve kâfir diye adlandırılan düşmanla yurtlarını ve evlatlarını korumak adına ölesiye savaşabildiklerini tespit etmek mümkündür.

"Kırk ince belli kız" vurgusu, bugünkü estetik anlayışla ince belli olmanın bir güzellik unsuru sayılmasından öte, savaşçı alp kadınların hızlı hareket etmesini sağlayan atletik bir vücuda sahip olduklarının ifade edilmiş biçimi olmalıdır. İnce bele sahip kızların at binmeleri de bu

15 Metin Ekici, "Dede Korkut Kitabında Kadın Tipleri” adlı makalesinde, Dede Korkut hikâyelerinde geçen "kırk ince belli kız" ifadesinin, farklı şekillerde değerlendirilmeğe müsait olduğunu, ancak söz konusu yardımcı karakterlerin sadece kadın ve erkek kahramanlar arasında eşitlik ve denge sağlamak açısından yer almış olabileceğini yazmıştır. Metin Ekici (2000). "Dede Korkut Kitabında Kadın Tipleri”, Uluslararası Dede Korkut Bilgi Şöleni Bildirileri (19-21 Ekim1999), Ankara Kültür Merkezi Yayınları, 394 s.

16 Mehmed Kaplan, "Dede Korkut Kitabında Kadın" makalesinde, Türk edebiyatında, "yaşanılan medeniyet dönemleri”ne göre kadını, üç kategoride sınıflandırmıştır: Bunlardan ilki, İslamiyet’ten önce ve göçebe dönemlerde o devrin ideal alp erkek tipine yaklaşan ata binen, ok atan, kılıç kullanan erkeğin yanında yer alan savaşçı kadın tipidir. Dede Korkut anlatılarında da bu ilk kategorideki kadın tipinin canlı bir şekilde tasvir edildiğini yazmaktadır. Mehmed Kaplan (1951). "Dede Korkut Kitabında Kadın". Türkiyat Mecmuas, Cilt: 9, s.99-112. 
anlamda daha kolay olacaktır. Bu aynı zamanda Türk destanları dikkate alındığında kurtların fiziksel özelliklerini de çağrıştırmaktadır. Kurtların belinin ince olması ve ince bacaklarının üzerinde yaylanışları, sıçrayışlarını ve buna bağlı olarak hareket kabiliyetlerini de artırmaktadır. Ayrıca kurtların da bir arada belli bir düzen içinde hareket etmelerinin gözlemlenmesi de o dönemin Türk savaş stratejisine katkı sağlamış olduğu söylencelerini de doğurmuştur.

\subsection{Dirse Han'ın Hatunu ve Kırk İnce Belli Kız}

Dede Korkut Kitabının ilk anlatısı olan "Dirse Han Oğlı Buğaç Han Boyı"nda, Dirse Han'ın Hatunu, ilk avına çıkan oğlu için yanındaki kızlarla birlikte herkesi davet edebilecekleri büyük bir toy düzenler; kızları da yanına alıp avdan dönen eşi, oğlu ve yanındakileri karşılamaya çıkar: "Dirse Hanun hatun oğlancuğumun ilk avddr diÿu atdan ayger deveden buğra koyundan koç kerdurd, kanlu Ö̆uz biglerin toylayayarm didi. Yumurlanup yirinden öri turdu, kırk ince kı̨ boyma aldr, Dirse Hana karşu vardi ${ }^{17}$."

Ancak oğlunu, babası ve onun kırk yiğidinin yanında göremez. Ana yüreği bir tehlike sezer ve kaygılanır oğlunun nerede olduğunu sorgular, Kocasının yanındaki kırk namert yiğit, Dirse Hanı konuşturmazlar. Bayındır Han'ın güçlü boğasını alt eden ve Dede Korkut tarafindan Boğaç adı verilen beyliği ilan edilen Boğaç Han ve yanındaki 40 genç yiğidi kıskanan Dirse Han'ın maiyetindeki yiğitler onun hala avda olduğunu ve geleceğini söylerler. Dirse Han'ın hatunu buna inanmaz, maiyetindeki 40 ince belli kızla birlikte oğlunu aramaya çıkar. Her türlü tehlikeyi dikkate alarak bir savaşçı gibi hazırlanıp dağ tepe aşarak oğlunu yaralı olarak bir dağın eteğinde bulur: "Dirse Hanun hatun kayntde girü

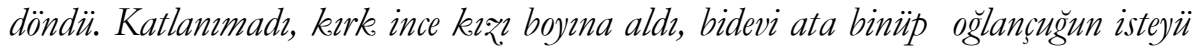

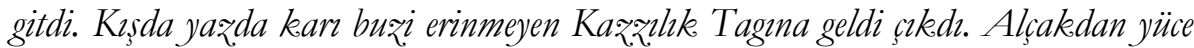
yirlere çapup çıkdı. Baksa görse bir derenün içine karga kuəgun iner çıkar, konar, kalkar. Bidevi atm ökegeledi, ol tarafa yorndin."

Dirse Han'ın hatunu namert 40 yiğidine kanan eşinin yaraladığ 1 oğlunu kurtarmak için Hızır'ın tavsiye ettiği otları bulup onlardan ilaç

7 Muharrem Ergin (1986). Dede Korkut Kitabı (Metin-Sözllïk), İstanbul: Ebru Yayınları, s.16.

18 Ergin, 1986: 18. 
yapmak için çiçek toplarlar: "Oğlan yine aydur: ana ağlamagl, mana bu yaradan ölüm yokdur, korhmagul, boz atlu Hızır mana geldi, üc kerre yaramı sığadı bu yaradan sana ölüm yokdur, tă̆ çiceği anan südi sana merhemdür, didi. Böyle digec

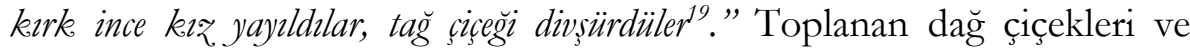
zorla sağılan anne sütü ile ilaç yapıp Boğaç Hanın yarasını saran Hatun ve maiyetindeki 40 ince belli kı Boğaç hanı babasından ve yanındaki namerd 40 yiğitten sır gibi saklayarak yurtlarına getirip onu iyileşinceye kadar hekimlere emanet ederler: "Oğlan ata bindürdiler, aluban ordusina gitdiler Oğlan bekimlere ısmarlayup Dirse Handan sakladılar 20."

$\mathrm{Bu}$ anlatıda Dirse Han'ın hatununun adı geçmez ama bey kızı olduğu ifade edilir, anlatının başından itibaren her problemde kocasının yanında yer aldığı, problem çözücü ve sağduyulu davrandığı, ailesini koruyup kolladığ1 ve düzeni sağlayarak baba ve oğul arasında bir köprü vazifesi yaptığı görülür. Aynı zamanda açların doyurulması, çıplakların giydirilmesi, borçlunun borcundan kurtarılmasının gerekliliğini vurgulayarak beyin görevlerini hatırlatır ve sosyal devlet anlayışının adeta altını çizer. O ve yanındaki 40 ince belli kızın bir örgütlü oluşum çerçevesinde anlatının kurgusuna doğrudan katkı sağladıkları ve anlatının şekillenmesinde rol aldıkları görülmektedir. Dolayısıyla anlatının satır aralarında, Bâcıyân-1 Rûm teşkilatındaki örgütlenmenin bir prototipinin varlı̆̆ hissedilmektedir.

\subsection{Burla Hatun ve Kırk İnce Belli Kız1}

Benzer bir durum "Salur Kazanun İvi Yağmalanduğ1 Boyu”nda da dikkat çekmektedir. Av sebebiyle erkeklerin yurttan uzak olduğu ve yurdun Salur Kazan'ın genç ve henüz kendini kanıtlayamamış olan oğlu Uruz'a teslim edilmesi sonucu, bunu casuslarından öğrenip pusu kurarak ve onları uykuda gafil avlayıp yurtlarını dağıtan düşmanlara, Bayındır Han'1n kiz1 ve Salur Kazan'in karısı Boyu uzun Burla hatunun, maiyetindeki kızlarla birlikte esir düşmesi anlatılmaktadır: "Ağır haz̧inesini bol akçasm yağmaladılar. Kirk ince billï kız-ile boyn uzun Burla Hatun yesir gitdi2."

\footnotetext{
Ergin,1986: 19.

20 Ergin,1986: 19.

21 Ergin,1986: 23.
} 
Bunu kara kaygılı bir rüya, yani bir kâbus olarak uykusunda gören Salur Kazan'ın yurduna geldiğinde her şeyin talan edildiğini görmesinin; annesinin, karısının, oğlunun ve tüm oba halkının esir düştüğünü öğrenmesinin ve onları kurtarma çabası içine girmesinin anlatıldığı hikâyede, düşmanın Salur Kazan'ı ve Bayındır Han'ı daha çok yaralamak için -birinin eşi diğerinin de kızı olan- Boyu uzun Burla Hatunu 40 ince belli kızın arasından seçmeye çalışması, ancak birlikte hareket eden kızların hatunu ele vermemeleri için strateji geliştirdikleri anlatılmaktadır: "Bu yana Şökli Melik kafirler-ile şin şadman yiyüp içüp oturur-idi. Aydur:Bigler bilür misiz. Kazana niçe hayf eylemek gerek. Boyn uzun Burla hatunun getürüp sagrak sürdürmek gerek didi. Boyn uұun Burla batun bun ișitdi, yüreği-y-ile canma odlar düsdi. Kırk ince billü kızun içine girdi, ögüt virdi, aydur: Kankinıqa yapısurlar-ise Kazan hatun kankinuzdur diyü, kirk yirden avaz viresiz, didi. ŞökliMelikeden adam geldi.Kazan Bigün hatum kankinuzdur didi. Kirk yirden avar, geldi kankisudur bilmediler ${ }^{22}$ ". Bu ifaden de anlaşıldığı üzere, kırk ince belli kızın kırkı da hatunun kendileri olduğunu söyleyerek hatunlarını düşmandan saklarlar.

Bir başka anlatı olan "Kazan Big Oğlı Uruz Bigün Tutsak Olduğ1 Boyı"nda, Burla Hatun tıpkı Dirse Hanın hatunu gibi ilk ava çıkan oğlu için toy düzenler. Oğlunu, avdan dönen babasının yanında görmeyince başına bir iş geldiğini anlar. Kazan'a hesap sorar ve eğer tutsak düşen oğlunu o kurtaramayacaksa kendisinin han babasına varacağını asker ve teçhizat alıp maiyetindeki kızlarla birlikte ölümü göze alıp oğlunu kurtarmaya gideceğini ifade eder $^{23}$. Kazan ve askerleri Oğlu Uruz'u kurtarmak için yola çıkarlar, ancak Burla Hatun dönmelerini bekleyemez yanına kırk ince belli kızı alıp oğlunu kurtarmaya gider: "Meger Hanum boyn

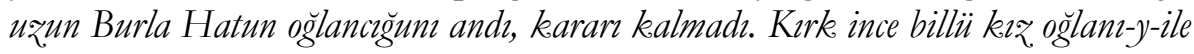
kara aygirn tartturd, butun bindi, kara kilhoun kuşandi. Başum tacı Kazan gelmedi diyü istedi gitti.Gelü gelü Kazana yaken geldi. Kazan halalm tanımadr.”

Kazan, yanındaki kızlarla birlikte gelen karısını tanımaz, kendisine yardıma gelen bir yiğit olduğunu sanır: "Kara aygirun cılavısım mana tartgıl

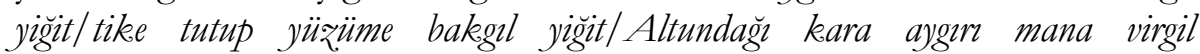
yiğit/Elündeki sivri cidam/Yanundaki göke, poladmo mana virgil yiğit/bu günümde

22 Ergin,1986:28.

23 Ergin,1986: 60 
umud olgzl mana/Kala ölke vereyim sana" diyerek karısı olduğunu bilmediği bu savaşç1 giyimli yiğide seslenir. Eşinin bu sözleri üzerine sinirlenen Burla Hatun uzun bir deyişinin sonunda "At üstinde eglenmeyüp yortan Kazan/ Senün belin ölmüss/ Üzengüye dirmeyen dizün ölümüss/ Han kızı halalun

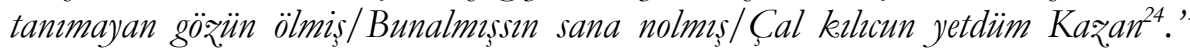
diyerek savaşan beylerin arasına karışır.

Diğer anlatılara baktığımızda da "Kam Pürenün Oğlı Bamsı Beyrek Boyı"nda da Banu Çiçek gerek beşik kertmesi Bamsı Beyrek ile ilk karşılaşmasında gerek dügünü esnasında ona yardımcı olan ve hizmetinde bulunan kadınlarla çevrilidir. Her firsatta onunla birlikte hareket eder ve ona destek çıkarlar. Düğün bölümünde Boyu Uzun Burla Hatun ve maiyetindeki kızlarında orada olduğu satır aralarından hissedilir, ozan kılı̆̆ındaki Beyrek'ten Banu Çiçek'i gizlemeye çalışan ve onun yerine çıkıp oynayan kadınlara ozan inanmayınca Burla Hatun Banu Çiçek'e kalkıp oynamasını söyler: "Burla Hatun aydur: Kız kalk oyna elünden ne gelür, didii ${ }^{25}$.

Maiyetlerindeki kırk ince belli kız ve diğer yardımcıları ile birlikte Dede Korkut hikâyelerindeki bey hatunları ya da kızları (Dirse Hanın Hatunu, Burla Hatun, Selcen Hatun, Banu Çiçek vd.) zaman zaman erkek kahramanlarla çeşitli nedenlerle karşı karşıya gelirler ve çıkan sonuç çoğu zaman doğrudan kurguya etki eder. Kadın karakterler, -birebir düşmanla savaşabildikleri gibi- genellikle erkeklerine yardımcı, yol gösterici, problemleri çözümleyici, düzenleyici ya da tehlikeli durumları engelleyicidirler. Kadınlar bu davranışlarıyla, erkeklerin öfkeli, kızgın, küskün, ani karar veren, savaşçı yanlarını da kendi uzlaşmacı tavırlarıyla dengelerler ${ }^{26}$

\section{DEĞERLENDİRME VE SONUÇ}

Bugün, Ahîlik Teşkilatının kadınlar kolu olarak değerlendirilen ve tarihsel süreç içerisinde sosyal hayatın her alanında faaliyetler gösteren; savunmadan savaşçılığa, el sanatlarından konuk ağırlamaya, yoksullara,

\footnotetext{
Ergin, 1986: 67

Ergin, 1986: 51

26 Deveci, Ümral (2017). Dede Korkut Anlatılarnda Doğa ve Kültür, Atatürk Kültür Merkezi Yayınları, Ankara, s.212.
} 
kimsesizlere kol kanat açmaktan, dini-tasavvufi anlayışın yaygınlaşmasına kadar pek çok görevi üstlenen Bâcıyân-1 Rûm teşkilatı kadınlarının, Avrupalı gezginleri ve tarihçileri şaşırtacak biçimde hiyerarşik bir düzen içerisinde Anadolu'da örgütlenmesi ve bunu asırlar boyu sürdürmesi pek çok açıdan önemlidir.

Ancak bu sosyal örgütlenmenin izlerini sürdüğümüzde, bu oluşumun aniden ortaya çıkmadığı aşikârdır. Orta Asya bozkırlarında tabiatın sertliği karşısında mücadele veren, düşman akınları karşısında hayatta kalma, savunma, savaşma başta olmak üzere, yaşadıkları topluluğa fayda sağlayarak ekonomik katma değer de kazandıran kadınların, benzer prototip örgütlenmelerle birbirlerine destek verdiklerini ve birbirlerinden güç aldıklarını sosyal tarih olarak nitelendirebileceğimiz halk anlatmalarında da görmekteyiz. Yazıya aktarılarak Dede Korkut Kitabı olarak bugüne ulaşmış destansı anlatmalarda da kırk ince belli kız olarak nitelendirilen ve bir bey hatununun liderliğinde hareket eden kadınlar, her ne kadar destansı anlatmaların satır aralarına sıkışmış olsalar da Bâcıyân-1 Rûm teşkilatındaki kadınlar gibi faaliyet gösterip hayatın her alanında birlikte var olmuşlar, anlatıların kurgusuna yön vermişlerdir. Kadın örgütlenmelerinin bu şekilde, yüzyılları aşıp gelmiş anlatmalarda yer almış olmaları onları tarihsel süreç içerisinde de gerçek kılmaktadır.

Pek çok çalışmada, Dede Korkut Kitabının Mukaddimesindeki biri makbul kadın, diğerleri eleştirilen üç kadın olmak üzere tasnif edilen dört tip kadının ve anlatılardaki bey hatunlarının ve kızlarının gölgesinde kalsalar da "kırk ince belli kız"ın oluşturduğu örgütlü topluluk ve üstlendikleri görevler, prototip bir sosyal örgütlenmenin, özellikle "kadın örgütlenmesi”nin varlığını göstermesi açısından dikkate değerdir. 


\section{KAYNAKÇA}

Bayram, Mikail (1999) "Bacıyan-Rum (Anadolu Bacıları) ve Fatma Bacı", Türkler Orta çağ, C.6, Ankara: Yeni Türkiye Yayınları, s. 365-379.

Çubukçu, Hatice (2015). "Bâcıyân-1 Rûm ve Anadolu Tasavvufundaki Yeri”, FSM İlmî Araștırmalar İnsan ve Toplum Bilimleri Dergisi, 5 Bahar, s.218-221.

Demiryürek, Meral (2017). "Kırk Kız Efsanesinin Yazılı Kültürdeki İki Örneği Üzerine Bir Değerlendirme”, Millı Folklor, Yıl: 29, Say1:116, s. 47-57.

Deveci, Ümral (2017). Dede Korkut Anlatılarnda Doğa ve Kültür, Atatürk Kültür Merkezi Yayınları, Ankara. 229 s.

Döğüs, Selahattin (2015). “Kadın Alplardan Baciyan-Rum'a (Anadolu Bacılar Teşkilatı); Türklerde Kadımm Siyasi ve Sosyal Mevkii, Cilt:12, Say1 1,s127-150.

Ekici, Metin (2000). "Dede Korkut Kitabında Kadın Tipleri", Uluslararası Dede Korkut Bilgi Şöleni Bildirileri (19-21 Ekim1999), Ankara Kültür Merkezi Yayınları, 394 s.

Ergin, Muharrem (1986). Dede Korkut Kitabı (Metin-Söqlük), İstanbul: Ebru Yayınları.

Kaplan, Mehmed (1951). "Dede Korkut Kitabinda Kadın". Türkiyat Mecmuası, Cilt: 9, s.99-112.

Tatlılıoğlu, Kasım (2012). "Ahîlik Teşkilatında Anadolu Türk Kadınının Girişimciliğine Sosyal-Psikolojik Bir Yaklaşım”, Bingöl Üniversitesi Sosyal Bilimler Enstitïsü Dergisi, Y11: 2/ Cilt: 2 /Say1: 4/ Güz. 